\title{
INDIVIDUAL AND ENVIRONMENTAL FACTORS ASSOCIATED WITH PENUMONIA IN CHILDREN UNDER FIVE IN MAGETAN, EAST JAVA, INDONESIA
}

\author{
Yola Alqorien Mustikarani'), Setyo Sri Rahardjo²), Isna Qadridjati²) \\ 1)Masters Program in Public Health, Universitas Sebelas Maret \\ ${ }^{2)}$ Faculty of Medicine, Universitas Sebelas Maret
}

\begin{abstract}
Background: Pneumonia represents an important threat to children's health in both developed and developing countries. Pneumonia is the leading killer of children under five worldwide. Pneumonia case in Magetan, East Java in 2017 was 1,833. This study aimed to examine the individual and environmental factors associated with pneumonia in children under five in Magetan, East Java.

Subjects and Method: A case control study was conducted in Magetan, East Java, from October to December 2018. A sample of 225 children under five was selected by fixed disease sampling. The dependent variable was pneumonia. The independent variables were nutritional status, vitamin A intake, maternal stress, maternal education, family income, smoking behaviour, cooking fuel, house physical environment, and the presence of infants in the kitchen. The data were collected by questionnaire and analyzed by a multiple logistic regression.

Results: Pneumonia in children under five increased with maternal stress $(b=1.91$; $95 \% \mathrm{CI}=0.75$ to $3.06 ; \mathrm{p}=0.001)$, parental smoking behavior $(\mathrm{b}=1.39 ; 95 \% \mathrm{CI}=0.46$ to 2.32; $\mathrm{p}=0.003)$, and infant presence in the kitchen $(\mathrm{b}=1.37 ; 95 \% \mathrm{CI}=0.38$ to $2.35 ; \mathrm{p}=$ $0.007)$, and smoke from cooking fuel $(\mathrm{b}=1.51 ; 95 \% \mathrm{CI}=0.46$ to $2.55 ; \mathrm{p}=0.005)$. Pneumonia in children under five decreased with good nutritional status $(b=-1.74 ; 95 \% \mathrm{CI}=$ -2.70 to $-0.78 ; \mathrm{p}<0.001)$, vitamin $\mathrm{A}$ intake $(\mathrm{b}=-1.14 ; 95 \% \mathrm{CI}=-2.04$ to $-0.24 ; \mathrm{p}=0.013)$, high maternal education $(\mathrm{b}=-1.41 ; 95 \% \mathrm{CI}=-2.45$ to $-0.37 ; \mathrm{p}=0.008)$, high family income $(b=-0.91 ; 95 \% \mathrm{CI}=-1.80$ to $-0.02 ; \mathrm{p}=0.045)$, and good house physical environment $(\mathrm{b}=-1.86 ; 95 \% \mathrm{CI}=-3.20$ to $-0.52 ; \mathrm{p}=0.007)$.

Conclusion: Pneumonia in children under five increases with maternal stress, parental smoking behaviour, and infant presence in the kitchen, and smoke from cooking fuel. It decreases with good nutritional status, vitamin A intake, high maternal education, high family income, and good house physical environment.
\end{abstract}

Keywords: pneumonia, biopsychosocial, environmental, determinant, children under five

\section{Correspondence:}

Yola Alqorien Mustikarani. Masters Program in Public Health, Universitas Sebelas Maret. Jl. Ir. Sutami 36A, Surakarta 57126, Central Java, Indonesia. Email: yolla.mstika@gmail.com. Mobile: +6285856122288

The $5^{\text {th }}$ International Conference on Public Health Best Western Premier Hotel, Solo, Indonesia, February 13-14, 2019 | 62 https://doi.org/10.26911/theicph.2019.01.08 